\title{
Studies on Removal of Cd 2+ using Chitosan Coated Carbon Biosorbent from Wastewater
}

\author{
M. Soundarrajan*, S. G. Gunasekaran, L. Devaraj Stephen \\ Department of Chemistry, SRM Valliammai Engineering College (Autonomous), \\ Kattankulathur, Tamil Nadu, India-603203. \\ E-mail: soundarrajanm.chemistry@valliammai.co.in
}

\begin{abstract}
Chitosan, a hydrophilic natural polymer produced by alkaline deacetylation of chitin, obtained mainly by extraction from shrimp and crab shells, is the most abundant biopolymer occurring in nature, after cellulose. It is composed of both glucosamine and acetylglucosamine as a monomer in the heteropolymeric network. It is characterized by a high content of nitrogen, present as amine groups capable of adsorbing the metal ions through several mechanisms - including chemical interactions, such as chelation, electrostatic interactions or ion exchange. In this study chitosan was coated on the carbon up to five coating. $5^{\text {th }}$ coated carbon was characterised by FTIR, TGA, DSC and XRD. FTIR study shows broad band at $3456.25 \mathrm{~cm}^{-1}$ was attributed to intermolecular hydrogen bonded $\mathrm{N}-\mathrm{H}$ stretching, $\mathrm{O}-\mathrm{H}$ starching and the strong polymeric association of chitosan coated carbon. TGA shows increase in thermal stability of the chitosan by coating on carbon. DSC shows single glass transition temperature $(\mathrm{Tg})$ due to attractive molecular interaction shows the polymer miscibility and compatibility of both materials. XRD shows sample having amorphous nature and the percentage of crystallinity is $18.7 \%$. After characterisation it was used for the adsorption study of $\mathrm{Cd}^{2+}$ from water by changing various parameters such as contact time, adsorbent dosage and pH. Optimum contact time was 300min with $71.5 \%$ removal of $\mathrm{Cd}^{2+}$, adsorbent dose was $5 \mathrm{~g}$ with $72.5 \%$ removal and $\mathrm{pH}$ was 5.5 with $77 \%$ removal. Sorption data were analysed by Langmuir and Freundlich adsorption isotherm. Sorption data well fitted to Freundlich isotherm than the Langmuir isotherm. Sorption data were used for kinetics study and it follows Pseudo-second-order kinetics.
\end{abstract}

Key words: Chitosan coated carbon, adsorbent dosage, pH, Isotherm, Kinetics

\section{Introduction}

Industrial activities such as metal finishing, paint pigments, battery manufacturing, leather tanning, mining activities, municipal wastewater sludges, urban composts, pesticides, phosphate fertilizers and atmospheric depositions are main sources for heavy metal pollutants [1]. Heavy metals in the environment are non-biodegradable. On the contrary, they can accumulate gradually and transferred into more toxic metal compounds, which causes adverse effects through bio-magnification of the food chain at all levels of the organisms in the ecosystem [2]. Some of the heavy metals like copper (Cu), Nickel (Ni), Zinc (Zn) are essential micronutrients for plants, but in excess all these metals are harmful to human health, 
animals and plants; as are the non-essential metals Lead $(\mathrm{Pb})$, cadmium $(\mathrm{Cd})$ and mercury (Hg) [3]. Municipal wastes, fertilizers, pesticides, sewage burning of fossil fuels, the mining and smelting of metallic ferrous ores are primary sources of above heavy metals [4]. For normal body functions a specific amount of chromium is required. Its higher concentration it may cause toxicity, including liver and kidney problems-genotoxic carcinogen [5].

Cadmium is a metal which is classified as human carcinogen and also considered to be toxic for plants [6]. Due to its non-corrosive behavior it has a number of industrial applications such as electroplating, pigments and paints. Cadmium enters the environment by anthropogenic pathways through industrial waste from process including, electroplating, mining, paint pigments, alloy preparation and batteries that contain cadmium [7]. Due to its non-corrosive nature, household appliances, automobiles, airplane parts, industrial tools, and factories of all kinds (e.g. nuts, bolts, screws and nails) are commonly cadmium coated and cadmium is also used in semiconductors, insecticides, nuclear reactor as control rods, luminescent dials, in photography, rubber curing and as fungicides [8].

Cadmium enters into the human beings and animals through biomagnifications; it causes health problems such as, itai-itai disease, renal damage, emphysema, hypertension and testicular atrophy [9]. It affects kidney cytochrome [10] increase the risk factor for breast cancer [11] formation of tumor and other adverse effects on reproductive organs like testis and placenta [12] in addition it also enhances the chance of tumour in testis, lungs, prostate and injection sites [13].

Heavy metal level in the waste water can be minimized by various technique such as ion exchange, chemical precipitation, membrane separation, coagulation and flocculation, electro-chemical method. But the above techniques are proved to be costly and ineffective especially when the metal ion concentration is low in the solutions [14].

Several non-conventional biosorbents have been investigated which includes banana pith [15], coir pith [16], bagasse pith [17], spent tea leaves [18] and coconut based biosorbents [19] are used as effective low cost adsorbents for the removal of heavy metals from water. Chitosan, a hydrophilic natural polymer produced by alkaline deacetylation of chitin, obtained mainly by extraction from shrimp and crab shells, is the most abundant biopolymer occurring in nature, after cellulose [20]. It is composed of both glucosamine and acetylglucosamine as a monomer in the heteropolymeric network. It is characterized by a high content of nitrogen, present as amine groups capable of adsorbing the metal ions through several mechanisms - including chemical interactions, such as chelation, electrostatic interactions or ion exchange. The interaction type depends on the metal ion, its chemistry and initial solution $\mathrm{pH}[21]$.

In order to increase the adsorption capacity of chitosan and to improve the adsorption selectivity of metal ions, several chemicals with certain functional groups have been loaded on chitosan such as isatin [22], diacetyl mono-oxime [23]. The above properties of chitosan also can be enhanced by grafting with new functional groups which includes poly 
(ethylenimine)[24], thiol [25], 3-amino-1,2,3-triazole-5-thiol [26] and crown ethers [27] through cross-linked chitosan backbone.

In this study, chitosan biopolymer was coated on activated carbon after characterisation it was used for the cost effective removal of $\mathrm{Cd}^{2+}$ ion from water. Sorption data were analysed to adsorption isotherm and kinetic study.

\section{Materials and methods:}

\subsection{Preparation of stock solutions}

Stock solutions of cadmium (II) were prepared by dissolving potassium cadmium chloride of $200 \mathrm{mg}$ per litre using double-distilled water and standardized after preparation. 1:1 Hydrochloric acid and $1 \%$ sodium hydroxide solutions were used for $\mathrm{pH}$ adjustment. The exact concentration of metal ion solution was calculated on mass basis and expressed in terms of $\mathrm{mg} \mathrm{L}^{-1}$. The required lower concentrations were prepared by dilution of the stock solution.

\subsection{Preparation of Chitosan coated carbon sorbent}

\subsubsection{Preparation of carbon}

The coconut shell was cut in to small pieces and ground. This was burnt at very high temperature for 5-6 hours. The surface of carbon obtained was activated by shaking the same with 7\% sulphuric acid for 24 hours. The carbon was then washed several times with deionised water till there was no acid in the water. The sulphonated carbon was dried in hot air oven for 5 hours at $110^{\circ} \mathrm{C}$.

\subsubsection{Surface coating of carbon with chitosan}

About $400 \mathrm{ml}$ of chitosan gel was diluted with water $(400 \mathrm{ml})$ and heated to $40-50^{\circ} \mathrm{C}$. About $400 \mathrm{~g}$ of activated coconut shell carbon was slowly added and mechanically agitated using a rotary shaker at $150 \mathrm{rpm}$ for 24 hours. This gel coated activated carbon was washed with deionised water and dried. This process was repeated to get $2^{\text {nd }}, 3^{\text {rd }}, 4^{\text {th }}$ and $5^{\text {th }}$ coating. Coating of chitosan on activated carbon $5^{\text {th }}$ was used for further the studies.

\subsection{3 $\mathrm{Cd}^{2+}$ removal by batch adsorption study}

Synthetic solutions of Cd (II) ions were taken in stoppered bottles and agitated with the prepared adsorbents separately at $30^{\circ} \mathrm{C}$ in orbit shaker at fixed speed of $160 \mathrm{rpm}$. The extent of heavy metal removal was investigated separately by changing adsorbent dose, contact time of shaking and changing $\mathrm{pH}$ of the solution.

After attaining the equilibrium the adsorbent was separated by filtration using filter paper and aqueous phase concentration of metal was determined with atomic absorption spectrophotometer (Varian AAA 220 FS).

\section{Characterisation of adsorbent}

\subsection{FT-IR study}

FT-IR spectrum of chitosan coated carbon shows a broad band observed at $3456.25 \mathrm{~cm}^{-1}$ was attributed to intermolecular hydrogen bonded N-H stretching, O-H starching and the strong polymeric association of chitosan coated carbon (Figure 1). The peak observed at $2924.68 \mathrm{~cm}^{-1}$ and $1628.22 \mathrm{~cm}^{-1}$ indicate the aliphatic asymmetric C-H stretching [28] and N- 
$\mathrm{H}$ bending. Certain peaks observed at $1384.35 \mathrm{~cm}^{-1}, 1115.56$ and $857.64 \mathrm{~cm}^{-1}$ corresponds to the $\mathrm{O}-\mathrm{H}$ in plane bending, $\mathrm{C}-\mathrm{O}-\mathrm{C}$ in glycoside linkage and $\mathrm{CH}_{3}-\mathrm{C}-\mathrm{OH}$ stretching respectively [28].

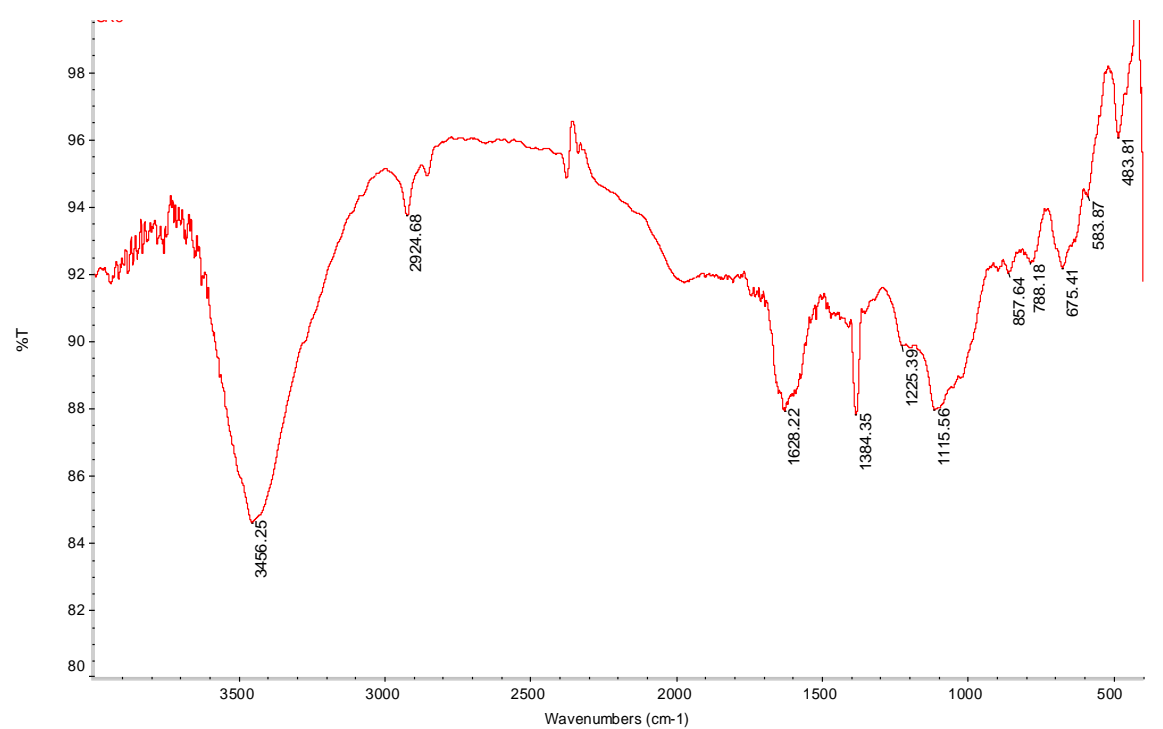

Fig. 1: FT-IR spectrum of chitosan coated carbon

\subsection{Thermogravimetric analysis}

The thermograms of chitosan coated carbon (Figure 2) were reported that around $50 \%$ of the composite had disintegrated in the temperature range of $476.64^{\circ} \mathrm{C}$. Two stage of decomposition were observed. The first weight loss was till $229^{\circ} \mathrm{C}$ due to the loss of absorbed moisture, elimination of water molecules and breaking up polymer linkages.

The second stage around $280^{\circ} \mathrm{C}-340^{\circ} \mathrm{C}$, due to elimination of organic compounds [29]. The third stage around $470^{\circ} \mathrm{C}-740^{\circ} \mathrm{C}$ may be due to degradation of chitosan molecules [30]. The maximum weight loss taking place at the temperature range from $245-400^{\circ} \mathrm{C}$. Around $72.65 \%$ of the sample had disintegrated at the temperature of range $743.28^{\circ} \mathrm{C}$ and at the end of the experiment $27.35 \%$ of the sample as a residue. As the amount of chitosan coated increases the thermal stability decreases as can be seen from Figure 2 .

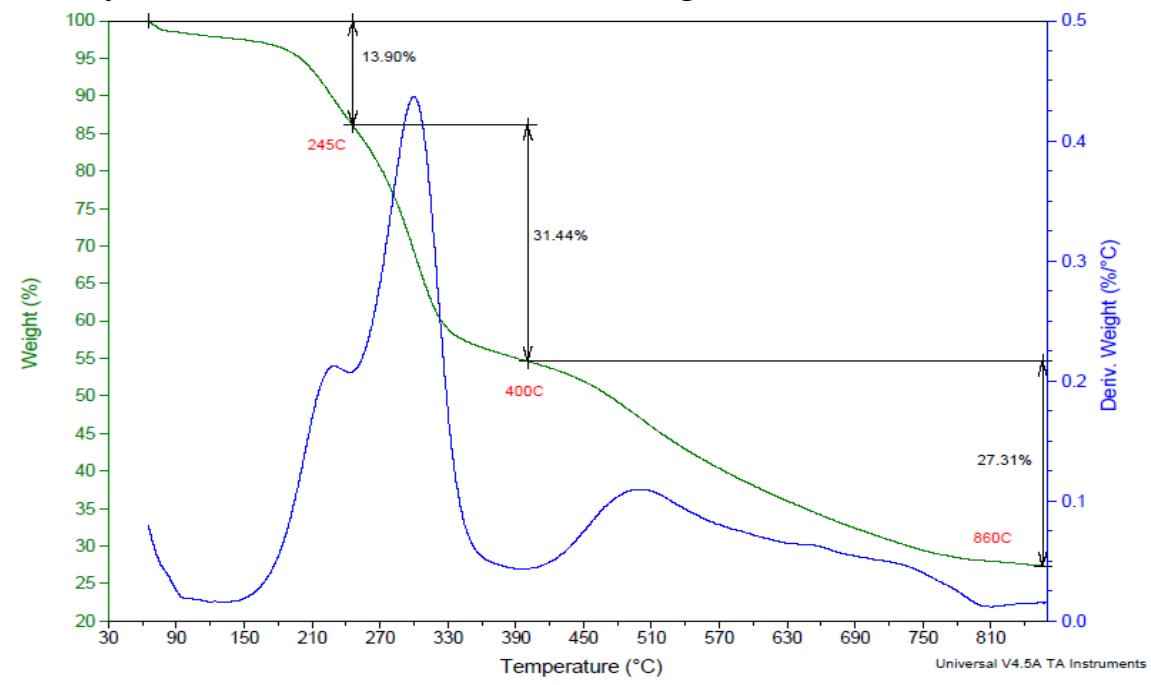

Fig. 2: TGA thermograms of biosorbent 
From the above data we observe that initial decomposition at $100^{\circ} \mathrm{C}$ all the chitosan coated carbon were $5 \%$ and the maximum decomposition of $60-70 \%$ happened within $750^{\circ} \mathrm{C}$, which is higher when compared with pure chitosan. This proves the increase in thermal stability of the chitosan by coating on carbon. Due to addition of carbon the thermal stability increases on compared to chitosan alone.

\subsection{Differential scanning calorimetric analysis}

The DSC curve of chitosan coated carbon showed that an endothermic was obtained at $78.27^{\circ} \mathrm{C}$ which shows the crystallization of the polymer and the glass transition temperature was found to be $180^{\circ} \mathrm{C}$. The single glass transition was indicative of attractive molecular interaction and high degree of compatibility of both materials (Figure 3).

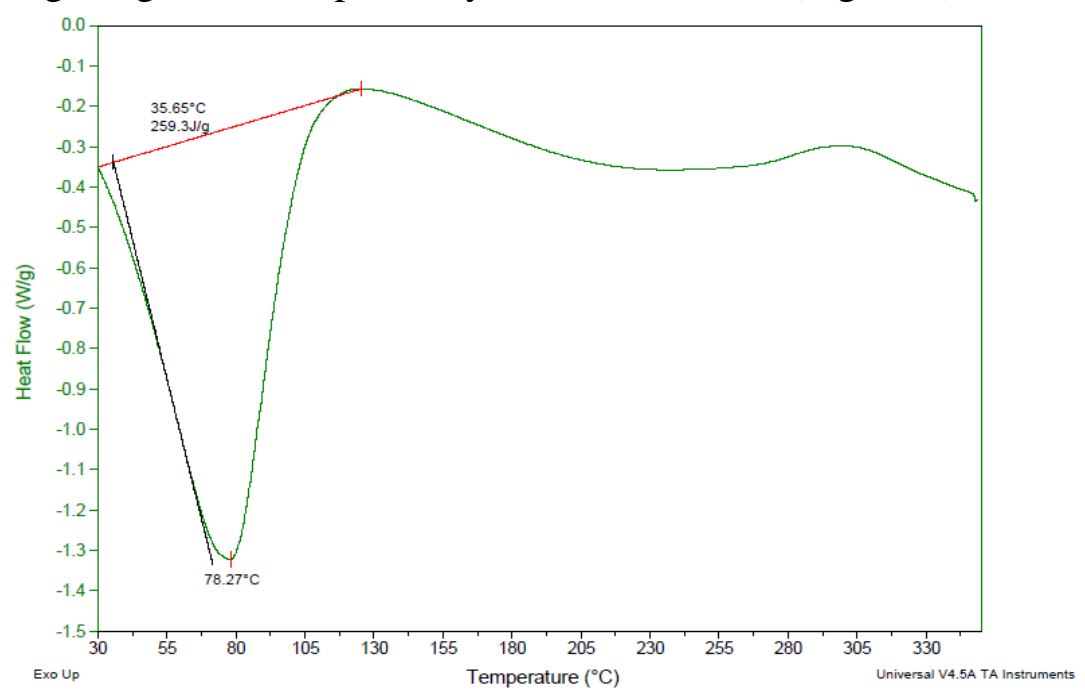

Fig. 3: DSC thermograms of biosorbent

Two stage of heating process was conducted for DSC analysis. The first stage heating used to decrease the water content in the films and release the stress. Since chitosan contains $-\mathrm{NH}_{2}$ and $-\mathrm{OH}$ functional groups, the hydrogen bonding is strongly formed among the molecules. The observation of single $\mathrm{Tg}$ in all chitosan coated carbon proved the complete mixing of two materials.

The shift in the crystallization temperature was seen when chitosan coated on carbon and there is no exothermic peak (Tm) till $330^{\circ} \mathrm{C}$ confirming the effective coating and increased thermal stability of the prepared material. Single glass transition temperature (Tg) obtained due to attractive molecular interaction shows the polymer miscibility and compatibility of both materials.

\subsection{X-Ray diffraction studies}

The XRD pattern (Figure 4) shows two short broad peaks at $2 \theta=16^{\circ}, 34^{\circ}$ which shows sample having amorphous nature and the percentage of crystallinity is $18.7 \%$. 


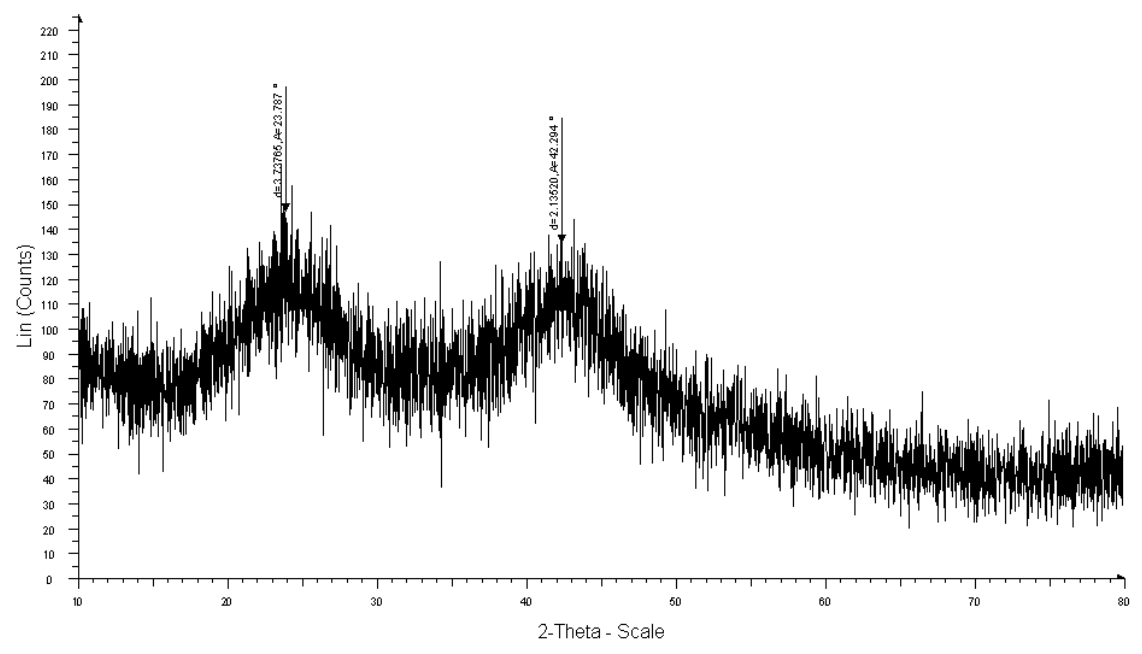

Fig. 4: XRD pattern of biosorbent

\section{Adsorption studies}

Study of metal adsorption properties of the chitosan coated carbon were carried out using a batch equilibrium procedure. Cd (II) ions were prepared in double distilled water. Batch experimental studies were carried out with $200 \mathrm{mg}$ of adsorbent in litter of Cd(II) solutions of desired concentration at an optimum pH 5.5 conical flasks. The flasks were agitated on orbit mechanical shaker at $190 \mathrm{rpm}$ for a known period of time at room temperature. After attaining equilibrium, adsorbent was separated by filtration using whatman filter paper and the aqueous-phase concentration of metal was determined with atomic absorption spectrophotometer (Varian AAA 220 FS).

The main objective of this study was to study adsorption characteristics of Cd (II) on chitosan coated carbon under equilibrium conditions and to understand the kinetics of adsorption. For this purpose, the effect of various factors affecting the adsorption process, such as time of contact, initial $\mathrm{pH}$ of the solution, and adsorbent dose were investigated. The experimental data were fitted to Freundlich and Langmuir isotherm model. The results were also analysed on the basis of Lagergren pseudo-first order and pseudo-second order kinetics equations.

\subsection{Effect of contact time}

It has been observed that at a constant concentration of metal ions and fixed amount of adsorbent, the adsorption efficiency increases with the increasing the contact time up to a certain level and then it reaches the equilibrium. It is observed that adsorption rate first increased rapidly as the contact time increases, but after reaching the optimum time of about 300 min there is no significant increase. The effect may be due to the saturation of adsorption sites with metal ions on the solid particle. 
Table 1: Effect of contact time

\begin{tabular}{|c|c|}
\hline Time (min) & $\mathbf{\% C}^{\mathbf{2 +}}$ removed \\
\hline 30 & 15.7 \\
\hline 60 & 27.1 \\
\hline 90 & 33.2 \\
\hline 120 & 41.4 \\
\hline 150 & 47.5 \\
\hline 180 & 54.5 \\
\hline 210 & 61.5 \\
\hline 240 & 67.4 \\
\hline 270 & 68.8 \\
\hline 300 & 71.5 \\
\hline 330 & 71.5 \\
\hline 360 & 71.5 \\
\hline
\end{tabular}

This result is important, as equilibrium time is one of the important parameters for an economical wastewater treatment system [31]. The equilibrium was attained due to the limited mass transfer of the adsorbate molecules from the bulk liquid to the external surface of the adsorbent [34].

The optimum contact time was 300 min with $71.5 \%$ adsorption (Table 1). The slight decrease in adsorption after optimum contact time may be due to the breakage of newly formed weak adsorption bonds due to constant shaking.

\subsection{Effect of adsorbent dose}

The effect of the adsorbent dose was studied at room temperature by varying the sorbent amounts from 1 to $6 \mathrm{~g}$ (Table 2). For all these runs, initial concentration of the metal ions was fixed. It is observed that the adsorption of Cd (II) ions increases rapidly with increase in the amount of adsorbent it is due to greater availability of the surface area. The significant increase in uptake was observed when the dose was increased from 1 to $5 \mathrm{~g}$.

Table 2: Effect of adsorbent dose

\begin{tabular}{|c|c|}
\hline Adsorbent dose $(\mathbf{g})$ & $\mathbf{\% C}^{\mathbf{2}} \mathbf{~ r e m o v e d}$ \\
\hline 1.0 & 45.5 \\
\hline 2.0 & 51.4 \\
\hline 3.0 & 63.6 \\
\hline 4.0 & 71.7 \\
\hline 5.0 & 72.5 \\
\hline 6.0 & 72.5 \\
\hline
\end{tabular}


Any further addition of the adsorbent beyond this did not cause any significant change in the adsorption. This may be due to overlapping of adsorption sites as a result of overcrowding of adsorbent particles. These results indicate that removal efficiency is directly related to the number of available adsorption sites. Once equilibrium is attained there is no effect on adsorption efficiency. Similar result was observed in studies done by Yee and Cybelle Morales Futalan (2018) [32, 33]. The optimum adsorbent dose was $5 \mathrm{gms} / \mathrm{L}$ with $72.5 \%$ removal of Cd (II) ions.

\subsection{Effect of pH}

The metal sorption and percentage removal from the aqueous solution are strongly affected by the $\mathrm{pH}$ of the solution [35]. The effect of $\mathrm{pH}$ change on adsorption was by changing the $\mathrm{pH}$ of the contents from 4-8, using dilute solutions of $\mathrm{HCl}$ and $\mathrm{NaOH}$ (Table 3). At low $\mathrm{pH}$ lower adsorption capacity Cd (II) ions was observed. This was due to the fact that at low $\mathrm{pH}$, amine groups in the chitosan gets protonated (surface active sites) and also there will be a repulsion force between heavy metal ions and active sites. This repulsion was reduced with rise the $\mathrm{pH}$, which is favouring the adsorption.

Table 3: Effect of pH

\begin{tabular}{|c|c|}
\hline $\mathbf{p H}$ & \% Cd $^{\mathbf{2}}$ removed \\
\hline 4.0 & 56 \\
\hline 4.5 & 60 \\
\hline 5.0 & 69 \\
\hline 5.5 & 77 \\
\hline 6.0 & 69 \\
\hline 6.5 & 62 \\
\hline 7.0 & 53 \\
\hline 7.5 & 44 \\
\hline 8.0 & 42 \\
\hline
\end{tabular}

Hence it shows increase in the adsorption of $\mathrm{Cr}$ (VI) and Cd (II) with increase the $\mathrm{pH}$ [36]. After $\mathrm{pH} 6$ adsorption of $\mathrm{Cd}$ (II) ions decreased which may be due to the precipitation of metal ions as insoluble hydroxides ${ }^{37}$ The optimum $\mathrm{pH}$ was 5.5 with $77 \%$ removal of $\mathrm{Cd}$ (II) ions.

\subsection{Isotherm studies}

It was observed that the $\mathrm{R}^{2}$ value was found to be 0.999 in Freundlich modelling (Table 4 $\& 5$ ). Hence $\mathrm{Cd}$ (II) ions onto the adsorbent correlates well with the Freundlich equation as compared to Langmuir equation under the various concentration ranges studied. These results indicate about feasibility of multilayer adsorption onto chitosan coated carbon and also the Freundlich constant ' $n$ ' shows the feasibility of heterogeneous adsorption (Figure $5 \& 6$ ). 
Table 4: Langmuir adsorption isotherm constant and coefficients

\begin{tabular}{|c|c|c|c|c|}
\hline \multirow{2}{*}{ Metal ions } & \multicolumn{4}{|c|}{ Langmuir constants } \\
\cline { 2 - 5 } & $\mathbf{K}_{\mathbf{L}}\left(\mathbf{d m}^{\mathbf{3}} / \mathbf{g}\right)$ & $\mathbf{b}\left(\mathbf{d m}^{\mathbf{3}} / \mathbf{m g}\right)$ & $\mathbf{C}_{\max }(\mathbf{m g} / \mathbf{g})$ & $\mathbf{R}^{\mathbf{2}}$ \\
\hline $\mathrm{Cd}$ (II) & 3.648 & 0.004385 & 831.93 & 0.8496 \\
\hline
\end{tabular}

Table 5: Freundlich adsorption isotherm constant and coefficients

\begin{tabular}{|c|c|c|c|}
\hline \multirow{2}{*}{ Metal ions } & \multicolumn{3}{|c|}{ Freundlich constants } \\
\cline { 2 - 4 } & $\mathbf{K}$ & $\mathbf{n}$ & $\mathbf{R}^{\mathbf{2}}$ \\
\hline Cd(II) & 0.3909 & 1.1299 & 0.9999 \\
\hline
\end{tabular}

\section{Cadmium}

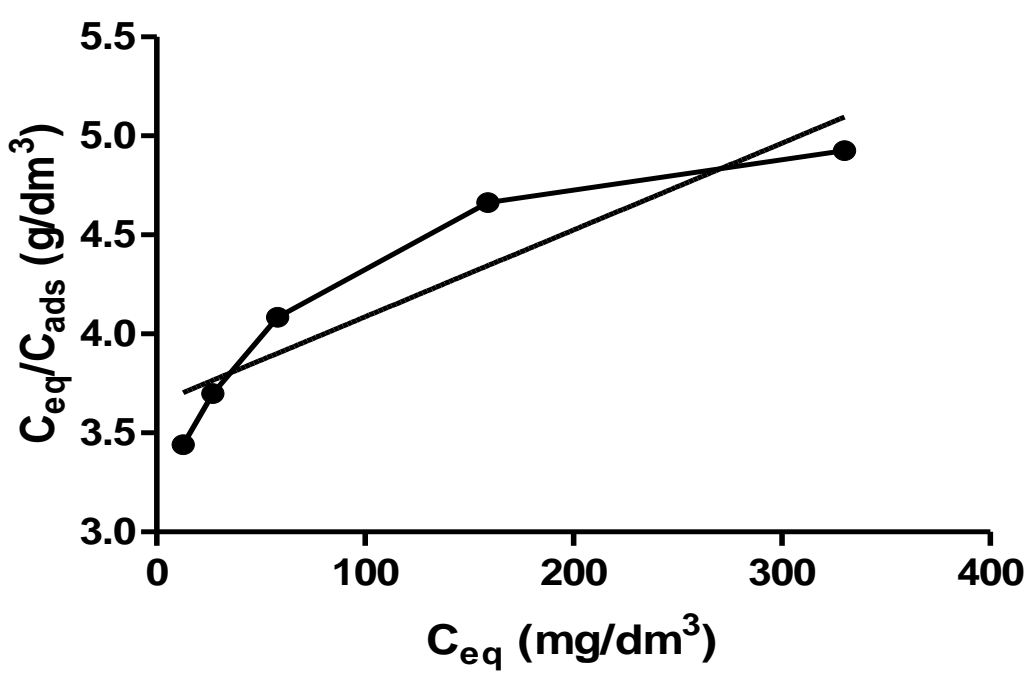

Fig. 5: Langmuir plot 
Cadmium

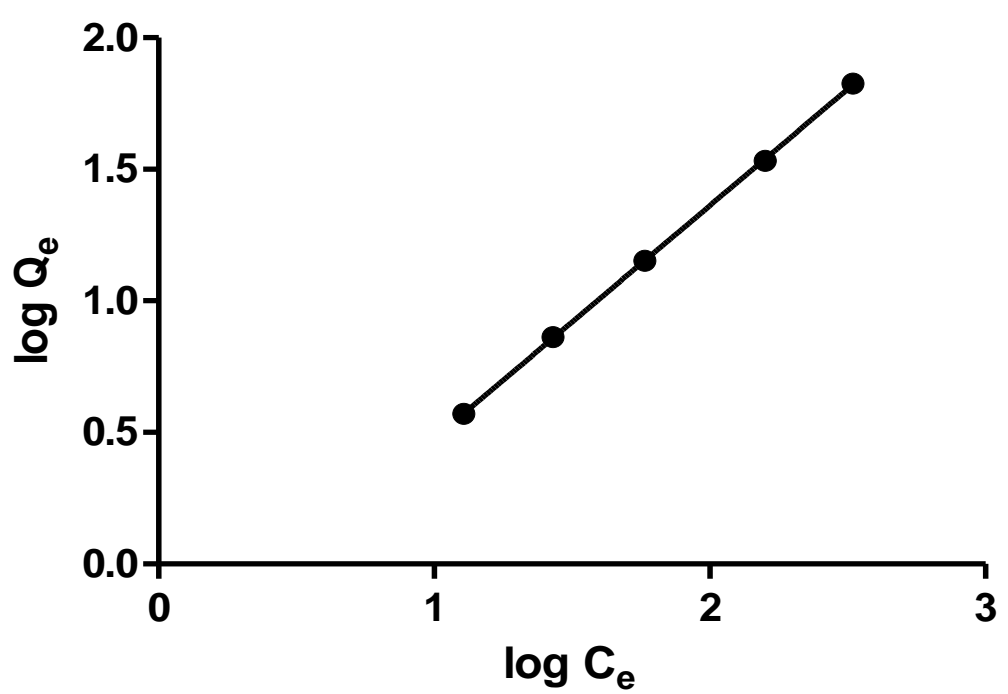

Fig. 6: Freundlich plot

\subsection{Kinetic study}

The results obtained from pseudo-first-order kinetics demonstrated that the experimental $\mathrm{q}_{\mathrm{e}}(\mathrm{mg} / \mathrm{g})$ values did not agree well with calculated value obtained from the linear plot. So adsorption process does not follow first order kinetics (Figure 7).

Cadmium

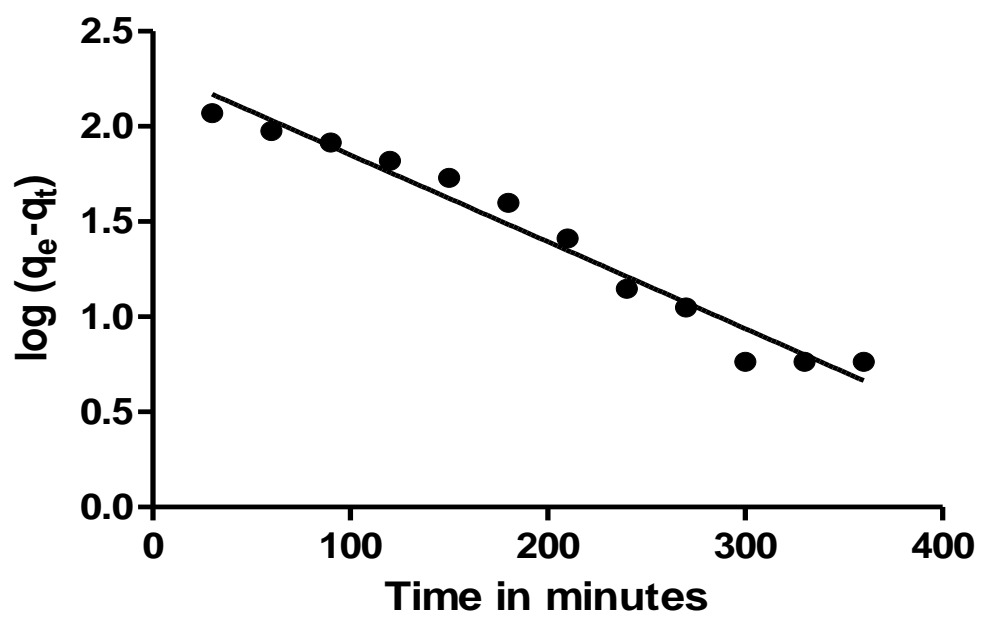

Fig. 7: Pseudo-first-order kinetics plot 


\section{Cadmium}

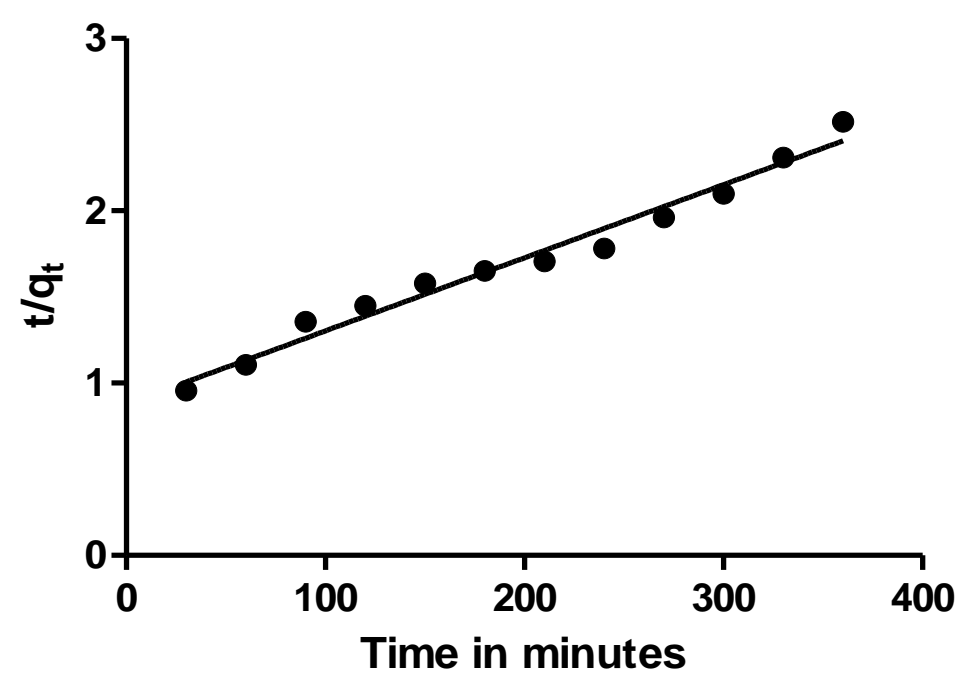

Fig. 8: Pseudo-second-order kinetics plot

But there will be a close agreement between experimental $\mathrm{q}_{\mathrm{e}}$ value and calculated $\mathrm{q}_{\mathrm{e}}$ value from pseudo-second -order model. This confirm that it is appreciable to use Largeegen second order model (Figure 8) to predict the adsorption kinetics $\mathrm{Cd}(\mathrm{II})$ ions onto chitosan coated carbon, which based on the assumption that the rate limiting step may be chemisorption involving valance forces through sharing and exchange of electrons as mentioned in Table 6 [37].

Table 6: Pseudo order kinetic models

\begin{tabular}{|c|c|c|c|c|c|c|c|}
\hline \multirow{2}{*}{$\begin{array}{c}\text { Metal } \\
\text { ion }\end{array}$} & \multicolumn{2}{|c|}{$\begin{array}{c}\text { Pseudo-first-order kinetic } \\
\text { model }\end{array}$} & $\begin{array}{c}\text { Experime } \\
\text { ntal value }\end{array}$ & \multicolumn{2}{|c|}{ Pseudo-second-order kinetic model } \\
\cline { 2 - 8 } & $\mathbf{q e}(\mathbf{m g} / \mathbf{g})$ & $\mathbf{k} \mathbf{( \mathbf { m i n } ^ { - 1 } )}$ & $\mathbf{R}^{\mathbf{2}}$ & $\mathbf{q}$ (mg/g) & $\mathbf{q e}(\mathbf{m g} / \mathbf{g})$ & $\mathbf{k} \mathbf{2}\left(\mathbf{g ~ m g}^{-1} \mathbf{~ m i n}^{-1}\right)$ & $\mathbf{R}^{\mathbf{2}}$ \\
\hline Cd(II) & 505.70 & 0.004562 & 0.9665 & 148.8 & 206.95 & 0.004244 & 0.9757 \\
\hline
\end{tabular}

\section{Conclusion}

Chitosan coated on carbon, after $5^{\text {th }}$ coating it is characterized by FTIR, TGA, DSC and XRD studies. FT-IR study showed that presence of amine and $\mathrm{OH}$ functional groups in the sorbent, which are responsible for the adsorption behaviour. It is noted that amount of adsorption various with following factors contact time, adsorbent dosage and $\mathrm{pH}$. Optimum contact time was 300min with $71.5 \%$ removal of $\mathrm{Cd}^{2+}$, adsorbent dose was $5 \mathrm{~g}$ with $72.5 \%$ removal and $\mathrm{pH}$ was 5.5 with $77 \%$ removal. Sorption data well fitted to Freundlich than the Langmuir isotherm and follows Pseudo-second-order kinetics. 


\section{References}

[1] A. Boularbah, C. Schwartz, G. Bitton, W. Aboudrar, A. Ouhammou, J.L. Morel, "Heavy metal contamination from mining sites in South Morocco: 2. Assessment of metal accumulation and toxicity in plants", Chemosphere. vol. 63, no.5, (2006), pp. 811-817.

[2] X. Q.Xu, C. Q. Qiu, G. Q. Deng, J. Y. Hui and X. H. Zhang, "Chemical ecological effects of mercury pollution in the three Gorges reservoir area”, Acta Hydrobiol. Sin. vol. 23, no. 3, (1999), pp. 97-203.

[3] R. D. Reeves and A. J. M. Baker, "Metal accumulating plants, In: I. Raskin, B. D. Ensley (Eds), Phytoremediation of toxic metals-using plants to clean up the Environment”, John Wiely \& Sons Inc. 193-229 (2000).

[4] J. Yoon, X. Cao, Q. Zhou and L.Q. Ma, "Accumulation of $\mathrm{Pb}, \mathrm{Cu}$ and $\mathrm{Zn}$ in native plants growing on a contaminated Florida site", Sci. Total Environ. vol. 368, (2006), pp. 456-464.

[5] S. Strachan, "Trace elements”, Curr. Anaesth. Crit. Care, vol. 21, (2010), pp. 44-48.

[6] J. Deckert, "Cadmium Toxicity a plants: is there any Analogy to its Carcinogenic Effect in Mammalian cells?”, Biometals. vol. 18, no. 5, (2005), pp. 475-481.

[7] M. Calero, F. Hernainz, G. Blazquez, G. Tenorio and M. A. Martin-Lara, "Study of Cr (III) biosorption in a fixed-bed column”, J. Hazard. Mater. vol. 171, (2009), pp. 886-893.

[8] D. C. Adriano, "Trace Elements in Terrestrial Environments", Biogeochemistry, Bioavailability, and Risks of Metals. Springer-Verlag. New York. 867 (2001)

[9] M. M. Rao, A. Ramesh, G. P. C. Rao and K. Seshaiah, "Removal of copper and cadmium from the aqueous solution by activated carbon derived from Ceiba pentendra hulls", J. Hazard. Mater. vol. 129, no. 1-3, (2006), pp. 165-129.

[10] A. Plewka, D. Plewka, G. Nowaczyk, M. M. Brzoska, M. Kaminski and M. J. Jakoniuk, "Effects of chronic exposure to cadmium on renal cytochrome P450-dependent monooxygenase msstem in rats", Arch. Toxical. vol. 78, no. 4, (2006), pp. 194-200.

[11] C. Giaginis, E. Gatzidou and S. Theocharis, "DNA repair systems as targets of cadmium toxicity”, Toxicol Appl. Pharmacol. vol. 13, no. 3, (2006), pp. 282-290.

[12] M. Takiguchi and S. Yoshihara, "New Aspects of cadmium as endocrine disruptor", Environ. Sci. vol. 13, no. 2, (2006), pp. 107-116.

[13] H. Koyama, H. Kitoh, M. Satoh and C. "Tohyama Low dose exposure to cadmium and its health effects (1). Genotoxicity and Carcinogenicity”, Nippon Eiseigaku Zasshi. vol. 57, no. 3, (2002), 547-555.

[14] S. R. Popuri, Y. Vijaya, V. M. Boddu and K. Abburi, "Adsorptive removal of copper and nickel ions from water using chitosan-coated PVC beads", Bioresource Technol. vol. 100, (2009), pp. 194-199.

[15] C. Namasivayam, D. Prabha and M. Kumutha, "Removal of direct red and acid brilliant blue by adsorption onto banana pith", Bioresour. Technol. vol. 64, (1998), pp. 77-79.

[16] C. Namasivayam, M. D. Kumar, K. Selvi, R. A. Begun, T. Vanathi and R. T. Yamuna, "Waste coir pith a potential biomass for the treatment of dyeing wastewaters", Biomass Bioenergy. vol. 21, (2001), pp. 477-483.

[17] B. Chen, C. W. Hui and G. McKay, "Film-pore diffusion modeling and contact time optimization for the adsorption of dyestuffs on pith", Chem. Eng. J. vol. 84, (2001), pp. $77-$ 94. 
[18] B. H. Hameed, "Spent tea leaves a non-conventional and low cost adsorbent for removal of basic dye from aqueous solution”, J. Hazard. Mater. vol. 161, (2009), pp. 753-759.

[19] A. Bhatnagar, V. J. P. Vilar, C. M. S. Botelho and R. A. R. Boaventura, "Coconut-based biosorbents for water treatment-A review of the recent literature”, Adv. Colloid Interface Sci. vol. 160, (2010), pp. 1-15.

[20] M. L. Arrascue, H. M. Garcia, O. Horna and E. Guibal, "Gold sorption on chitosan derivatives", Hydrometallurgy. vol. 71, (2003), pp. 191-200.

[21] M. S. D. Erosa, T. I. S. Medina, R. N. Mendoza, M. A. Rodriguez and E. Guibal, "Cadmium sorption on chitosan sorbents: Kinetic and equilibrium studies", Hydrometallurgy. vol. 61, no. 3, (2001), pp. 157-167.

[22] M. Monier, B. D. M. Ayad, Y. Wei and A. A. Sarhan, "Preparation and characterization of magnetic chelating resin based on chitosan for adsorption of $\mathrm{Cu}$ (II), Co (II), and Ni (II) ions", React. Funct. Polym. vol. 70, (2010), pp. 257-266.

[23] M. Monier, B. D. M. Ayad, Y. Wei and A. A. Sarhan, Adsorption of Cu (II), Co (II), and Ni(II) ions by modified magnetic chitosan chelating resin”, J. Hazard. Mater. vol. 177, (2010), pp. 962-970.

[24] J. D. Merrifield, W. G. Davids, J. D. MacRae and A. Amirbahman, "Uptake of mercury by thiol-grafted chitosan gel beads”, Water Res. vol. 38, (2004), pp. 3132-3138.

[25] A. A. Atia, "Studies on the interaction of mercury (II) and uranyl (II) with modified chitosan resins", Hydrometallurgy. vol. 80. (2005), pp. 13-22.

[26] Z. Yang, Y. Yuan and Y. Wang, "Synthesis and evaluation of chitosan aryl azacrown ethers as adsorbents for metal ions", J. Appl. Polym. Sci. vol. 77, (2000), pp. 3093-3098.

[27] G. A. Latha, K. B. George, G. K. Kannan and N. K. Ninan Synthesis of a polyacrylamide chelating resin and applications in metal ion extractions, J. Appl. Polym. Sci. vol. 43, (1991), pp. 1159-1163.

[28] M. A. S. Spinace, C. S. Lambert, K. K. G. Fermoselli and M. A. De Paoli, "Characterization of lignocellulosic curaua fibers", Carbohydr Polym. vol. 77, no. 1, (2009), pp. 47-53.

[29] G. Yan and T. Viraraghavan, "Mechanism of biosorption of heavy metals by Mucor rouxii, Eng. Life Sci. vol. 8, (2008), pp. 363-371.

[30] C. H. Chen, F. Y. Wang, F. Fengmao, W. T. Liao and C. D. Hsieh, "Studies of chitosan: II. Preparation and Characterisation of chitosan /poly(vinyl alcohol) gelatin ternary blend films", Int. J. Biol. Macromol. vol. 43, (2008), pp. 37-42.

[31] S. Gueu, B. Yao, K. Adouby, and G. Ado, "Kinetic and thermodynamic study of lead adsorption onto activated carbon from coconut shell and seed hull palm tree”, Int. J. Environ. Sci. Tech. vol. 4, (2007), pp. 11-17.

[32] J. J. Yee, C. V. J. Arida, C. M. Futalan, M. D. G. Luna, and M. W. Wan, "Treatment of Contaminated Groundwater via Arsenate Removal Using Chitosan-Coated Bentonite”, Molecules, vol. 24, no. 13, (2019), pp. 2464-2479.

[33] C. M. Futalan, Y. S. Huang, J. H. Chen, M. W. Wan, "Arsenate removal from aqueous solution using chitosan-coated bentonite, chitosan-coated kaolinite and chitosan-coated sand: Parametric, isotherm and thermodynamic studies". Water Sci. Technol. vol. 78, (2018), pp. 676-689. 
[34] M. Monier, B. D. M. Ayad and A. A. Sarhan, "Adsorption of Cu (II), Hg (II), and Ni (II) ions by modified natural wood chelating fibers”, J. Hazard. Mater. vol. 176, pp. (2010), pp. 348355.

[35] M. Horsfall Jr. and A. A. Abia, "Sorption of cadmium (II) and zinc (II) ions from aqueous solution by cassava waste biomass (manihot sculenta cranz)”, Water Res. vol. 37, no. 20, (2003), pp. 4913-4923.

[36] W. S. W. Ngah, S. Fatinathan, "Adsorption characterization of Pb (II) and Cu (II) ions onto chitosan-tripolyphosphate beads: Kinetic, equilibrium and thermodynamic studies”, J. Environ. Manage. vol. 91, (2010), pp. 958-969.

[37] S. S. Gupta, K. G. Bhattacharyya, "Immobilization of Pb(II), Cd(II) and Ni(II) ions on kaolinite and montmorrillonite surfaces from aqueous medium”, J. Environ. Manage. vol. 87, (2008), pp. 46-58. 